\title{
PEDIASTRUM SPECIES (HYDRODICTYACEAE, SPHAEROPLEALES) IN PHYTOPLANKTON OF SUMIN LAKE (ŁĘCZNA-WŁODAWA LAKELAND)
}

\author{
AgnieszKa PaszTaleniec, MaŁgorzata PoniewozIK \\ Department of Botany and Hydrobiology, Catholic University of Lublin \\ C.K. Norwida 4, 20-061 Lublin, Poland \\ e-mail: paszta@kul.lublin.pl
}

(Received: April 7, 2003. Accepted: July 18, 2003)

\begin{abstract}
During studies of phytoplankton in Sumin Lake (Łęczna-Włodawa Lakeland), conducted from May till September 2001 and 2002, 15 taxa of the genus Pediastrum (Hydrodictyaceae, Sphaeropleales) were found. Among them there were common species as Pediastrum boryanum, P. duplex, P. tetras and P. simplex, but also rare species as $P$. integrum or $P$. kawraiskyi. An especially interesting species was $P$. orientale, the taxon that until now has not been noted in phytoplankton of Polish water bodies. The paper gives descriptions of the genus Pediastrum coenobia and physico-chemical conditions of the habitat. The original documentation of Pediastrum taxa is added.
\end{abstract}

KEY WORDS: Pediastrum taxa, Chlorophyta, phytoplankton, Łęczna-Włodawa Lakeland.

\section{INRTODUCTION}

Lakes of Łęczna-Włodawa Lakeland are the only group in Poland located beyond the limits of a continental glacier of the last glaciation. The genesis of lakes is still disputable, but the most of them have a termo-karst origin (Harasimiuk and Wojtanowicz 1998). The lakes are in different succession stages and are of different trophic character. The Łęczna-Włodawa Lakeland has the specific qualitative differentiation of algae in comparison with others lakelands in Poland. Some rare species as Fragilaria reicheltii (=Centronella rostafinskii) or Gonatozygon aculeatum var. groenbladii were found here (Wojciechowski 1983). Nevertheless, there have been very few taxonomic researche of phytoplankton species in Łęczna-Włodawa lakes. In the paper we present the phytoplankton of the shallow, eutrophic lake - Sumin and our special object of interest was genus Pediastrum (Hydrodictyaceae, Sphaeropleales), which appeared there in a great species diversity. These planktic species are frequent in algal communities of ponds and lakes. The Pediastrum genus is well known both from taxonomical and ecological points of view; among others Sulek (1969), Komárek and Fott (1983), Komárek and Jankovská (2001) presented reviews of the Pediastrum. The outer layer of Pediastrum cell wall is composed of sporopollenin combined with silicon oxide which causes its high resistance to decay. Therefore, several species occur commonly in the fossil record, and they are frequently obse- rved in palynological preparations (Jankovská and Komárek 2000, Komárek and Jankovská 2001; Nielsen and Sørensen 1992).

The taxonomical research of the genus Pediastrum was not conducted in phytoplankton of Łęczna-Włodawa Lakeland lakes. Only some information on occurrence of this genus are included in works of Wojciechowski (1971) and Malicki (1972). Some data on fossil Pediastrum gives Bataga (1998). In our work we present information of several Pediastrum species and varieties. The keys of Komárek and Fott (1983) and Komárek and Jankovská (2001) were used for determining of the taxa.

\section{STUDY AREA, MATERIAL AND METHODS}

Lake Sumin is situated in the central part of the ŁecznaWłodawa Lakeland (Eastern Poland), in the buffer zone of the Polesie National Park (Fig. 1). It is a shallow (max. depth $6.5 \mathrm{~m}$, mean depth $2 \mathrm{~m}$ ), dimictic and eutrophic water body (Radwan and Kornijów 1998). This area is 84.5ha. The north waterside of the Sumin Lake is surrounded by bogs.

The physico-chemical water parameters of Sumin Lake were as follows: $\mathrm{pH}$ - from 8.4 to 8.8 ; temperature - from 12.1 to $23.4^{\circ} \mathrm{C}$; oxygenation - from 7.7 to $9.2 \mathrm{mg} / \mathrm{dm}^{3}$; conductivity - from 376 to $660 \mu \mathrm{S} / \mathrm{cm}^{2}$, and the SD values during studies were about $0.7-1.0 \mathrm{~m}$. The contents of the 


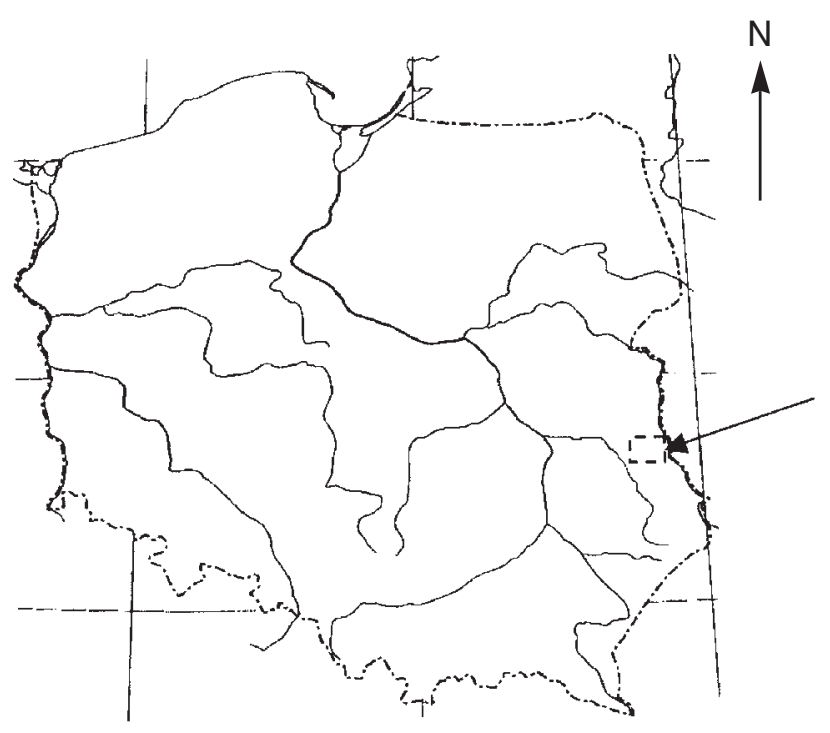

Fig. 1. Location of Łęczna-Włodawa Lakeland. Scale bars: $10 \mu \mathrm{m}$.

main nutrients were (in $\mathrm{mg} / \mathrm{dm}^{3}$ ): $\mathrm{N}-\mathrm{NH}_{4}: 0.66-0.8 ; \mathrm{N}^{-N_{3}}$ : $0.11-0.24 ; \mathrm{P}_{-} \mathrm{PO}_{4}: 0.002-0.03 ; \mathrm{P}_{\text {tot }}: 0.08-0.14 ; \mathrm{N}_{\text {tot }}: 0.52-$ -2.24. Chlorophyll-a concentration was between 14-37 $\mu \mathrm{g} / \mathrm{dm}^{3}$. Conductivity and acidity of water were measured under field conditions. The other analyses of water were made in a laboratory.

Qualitative studies of phytoplankton were carried out in the pelagic zone in the years 2001 and 2002. The samples were collected from May till September in one-month intervals, using a plankton net (mesh size $35 \mu \mathrm{m}$ ). The studies were carried out on living and preserved material (formaldehyde-glycerin solution were used). Observations were made with a Nikon Eclipse E 200 light microscope equipped with an oil-immersion objective, and photos with $\mathrm{Ni}$ kon FDX-35. For each found species microphotographs or drawings were made.

Taxonomical descriptions of taxa were determined on the basis of morphological features such as: outline of cells, number of lobes and processi, depth of incisions in marginal cells, sculpture of cell wall. Cells dimensions given in description concern the relations: width $\times$ length. In the case of marginal cells the length of a cell includes length of lobes and processi. All observations were made using light microscopy under immersion (with focus level $\times 2000$ ).

\section{RESULTS AND DISCUSSION}

During the studied period the phytoplankton of Sumin Lake was dominated by Chlorophyta (about $70 \%$ share in the total numbers of phytoplankton) and Cyanoprokaryota algae (30\% of phytoplankton abundance). None of the species reached a strong quantitative predominance, but the most frequent among Chlorophyta were: Tetraëdron minimum, Scenedesmus spp., Coelastrum sphaericum, Oocystis lacustris; among species belonging to Cyanoprokaryota: Aphanothece clathrata, Chroococcus limneticus, Microcystis aeruginosa and Lyngbya sp. Green-algae had not only a high percentage share, but were also characterized by a high biodiversity. A special species richness was observed in the genus Pediastrum (Hydrodictyaceae, Sphaero- pleales). In spite of the great biodiversity (11 species and 15 with all varieties) this genus never dominated in total number of planktic algae.

The genus Pediastrum consists of colonial green algae, which occur naturally in freshwater environments, in particular in standing water bodies (Nicholls 1997; Reynolds 1980; Sitkowska 1992). Many species of these algae have been described. Nowadays 24 species are known from this genus, but only four have a really world-wide distribution (P. boryanum, $P$. duplex, $P$. tetras and $P$. simplex), other taxa belong to a wide range of various ecologically and geographically different types (Komárek and Jankovská 2001). Among world-wide distributed taxa, several varieties of $P$. boryanum, $P$. duplex and $P$. tetras could be dominant in eutrophic reservoirs of the temperate zone. $P$. simplex occurs in the temperate zone in lower frequency in warm seasons. We determined many of cosmopolitan, commonly distributed taxa (f.e. Pediastrum boryanum (Turpin) Menegh. var. boryanum, $P$. duplex (Meyen) var. duplex, P. tetras (Ehrenberg)), and also rare species and varieties (f.e. $P$. kawraiskyi (Schmidle), P. integrum (Nägeli) or P. orientale (Skuja) Jankovská et Komárek.

The results of our observations are presented below.

\section{World-spread, usually common taxa:}

Pediastrum boryanum (Turpin) Menegh. var. boryanum (Fig. 2)

Coenobia (40.0-103.7 $\mu \mathrm{m})$ circular or irregular in outline. Coenobia always without holes, 16-32 cells. Marginal cells $(10.0-13.6 \times 13.0-27.2 \mu \mathrm{m})$ with two lobes ending in two narrow processi. Inner cells: $10.0-14.8 \times 9.8-17.8 \mu \mathrm{m}$. Incision between processi $\mathrm{V}$-shaped. Cell wall regularly granular. Occurred very often in studied samples.

According to Komárek and Jankovská (2001) this species is typical of slightly alkaline, eutrophic, but not polluted waters.

Pediastrum boryanum (Turpin) Menegh. var. brevicorne A. Braun (Fig. 3)

Coenobia circular with $14-16$ cells, without holes. Diameter of coenobium from 59.3 to $61.8 \mu \mathrm{m}$. Marginal cells with two very short processes. Dimensions of marginal and inner cells: $10.0-14.8 \times 12.3-16.0 \mu \mathrm{m}$. Cell wall granular. Incision shallow, in shape of U.

Recently known as termophilic, occurring in tropical countries up to warmer regions of temperate zone (Komárek and Jankovská 2001).

Pediastrum boryanum (Turpin) Menegh. var. longicorne Reinsch (Fig. 4)

Coenobia without holes, 32 celled $39.5-170 \mu \mathrm{m}$ in diameter. Dimensions: marginal cells with two long processes slightly curved, 6.2-12.3 $\mu \mathrm{m}$ wide, 10.0-15.0 $\mu \mathrm{m}$ long. Inner cells: $7.4-34 \times 4.9-22.5 \mu \mathrm{m}$. Cell walls scarcely granular. Incision shallow.

Species ecologically restricted (peaty waters) known from all climatic zones (Komárek and Jankovská 2001). Based on cell wall sculpture variety longicorne stands out by having the most constant set of characters and is the most easily recognized variety of $P$. boryanum (Nielsen 2000). 

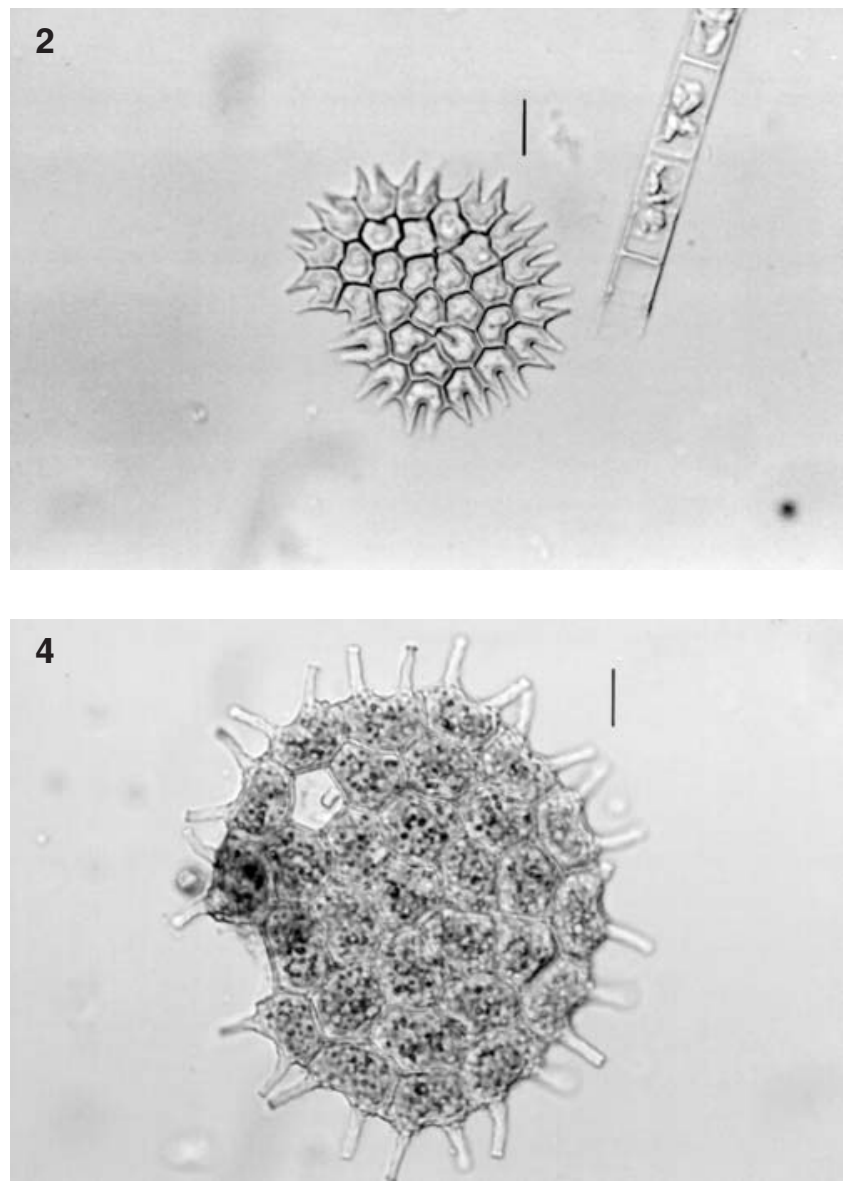

6

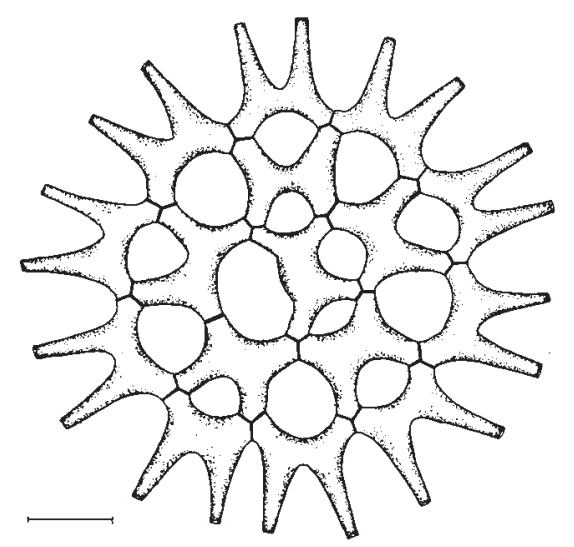

3
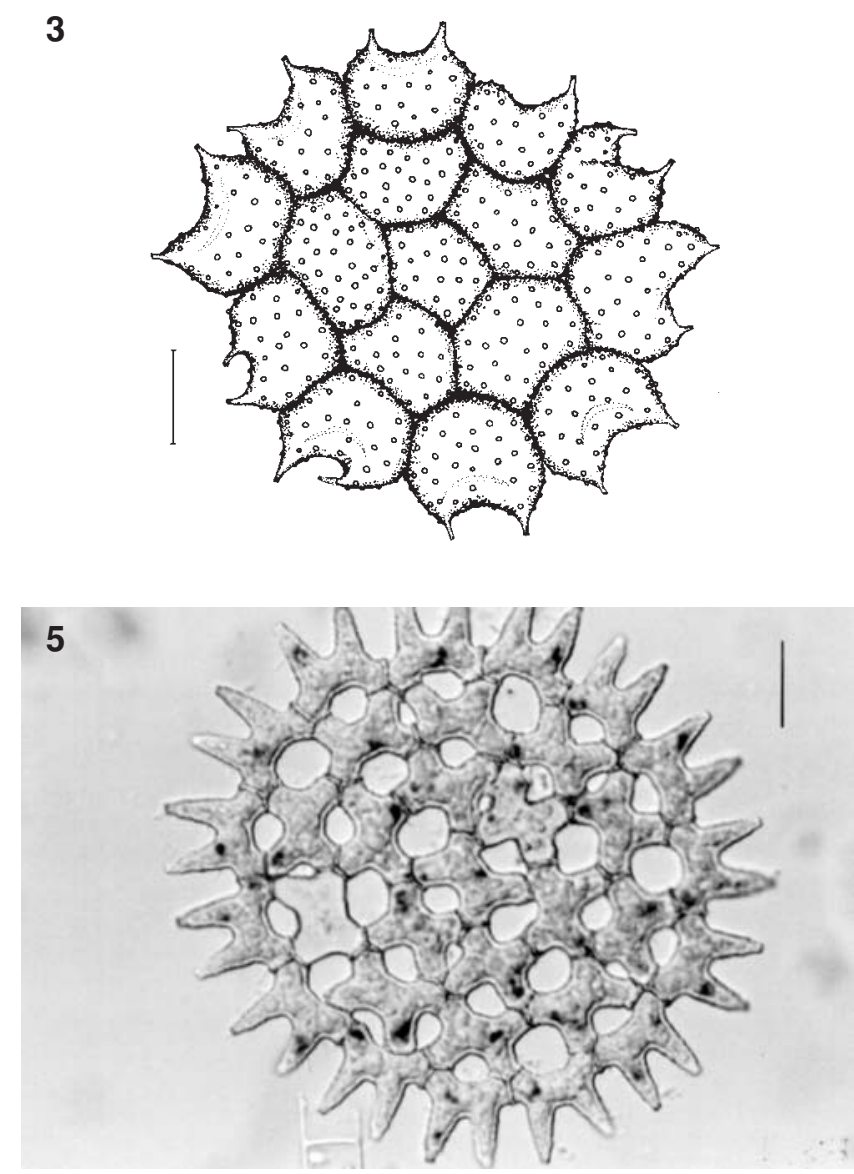

7

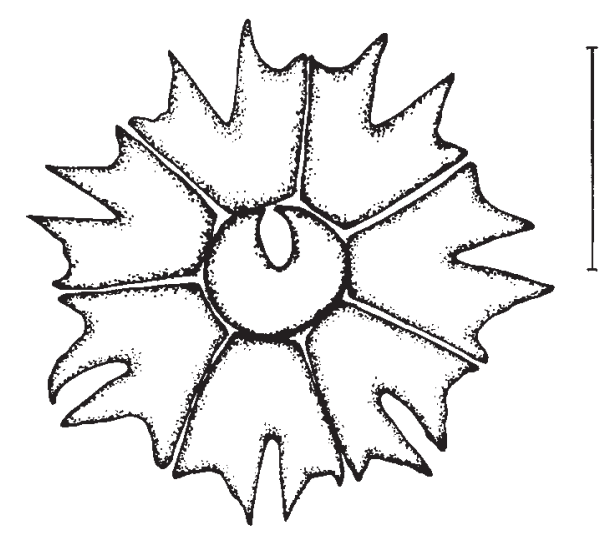

Fig. 2. Pediastrum boryanum (Turpin) Menegh. var. boryanum. Scale bars: $10 \mu \mathrm{m}$. Focus level $800 \times$.

Fig. 3. Pediastrum boryanum (Turpin) Menegh. var. brevicorne A. Braun. Scale bars: $10 \mu \mathrm{m}$.

Fig. 4. Pediastrum boryanum (Turpin) Menegh. var. longicorne Reinsch. Scale bars: $10 \mu \mathrm{m}$. Focus level 800x.

Fig. 5. Pediastrum duplex (Meyen) var. duplex. Scale bars: $10 \mu \mathrm{m}$. Focus level 1200×.

Fig. 6. Pediastrum duplex (Meyen) var. gracillimum. Scale bars: $10 \mu \mathrm{m}$.

Fig. 7. Pediastrum tetras (Ehrenberg). Scale bars: $10 \mu \mathrm{m}$.

\section{Pediastrum duplex (Meyen) var. duplex (Fig. 5)}

Coenobia circular, 44.5-222.2 $\mu \mathrm{m}$ in diameter (the most of individuals found had more then $100 \mu \mathrm{m}$ ) with regularly distributed holes, with 32-64 cells arranged concentrically. Incision between processi V-shaped. Marginal cells 7.4$-19.8 \times 10.0-24.7 \mu \mathrm{m}$, inner cells almost quadratic, their diameter 10.0-12.5 $\mu \mathrm{m}$. Cell walls with very fine sculpture visible under immersion. This species was the most frequent in net-samples from Sumin Lake.
Typical of water bodies in temperate zone, probably with naturally increasing trophic level (Komárek and Jankovská 2001).

Pediastrum duplex (Meyen) var. gracillimum (Fig. 6)

Coenobia circular (40.0-63.0 $\mu \mathrm{m}$ in diameter) with great holes between cells (much larger than in P. duplex var. $d u$ plex). Coenobia composed of 8-16 cells. Marginal cells with distinct $\mathrm{V}$-like incision between two long, cylindrical 

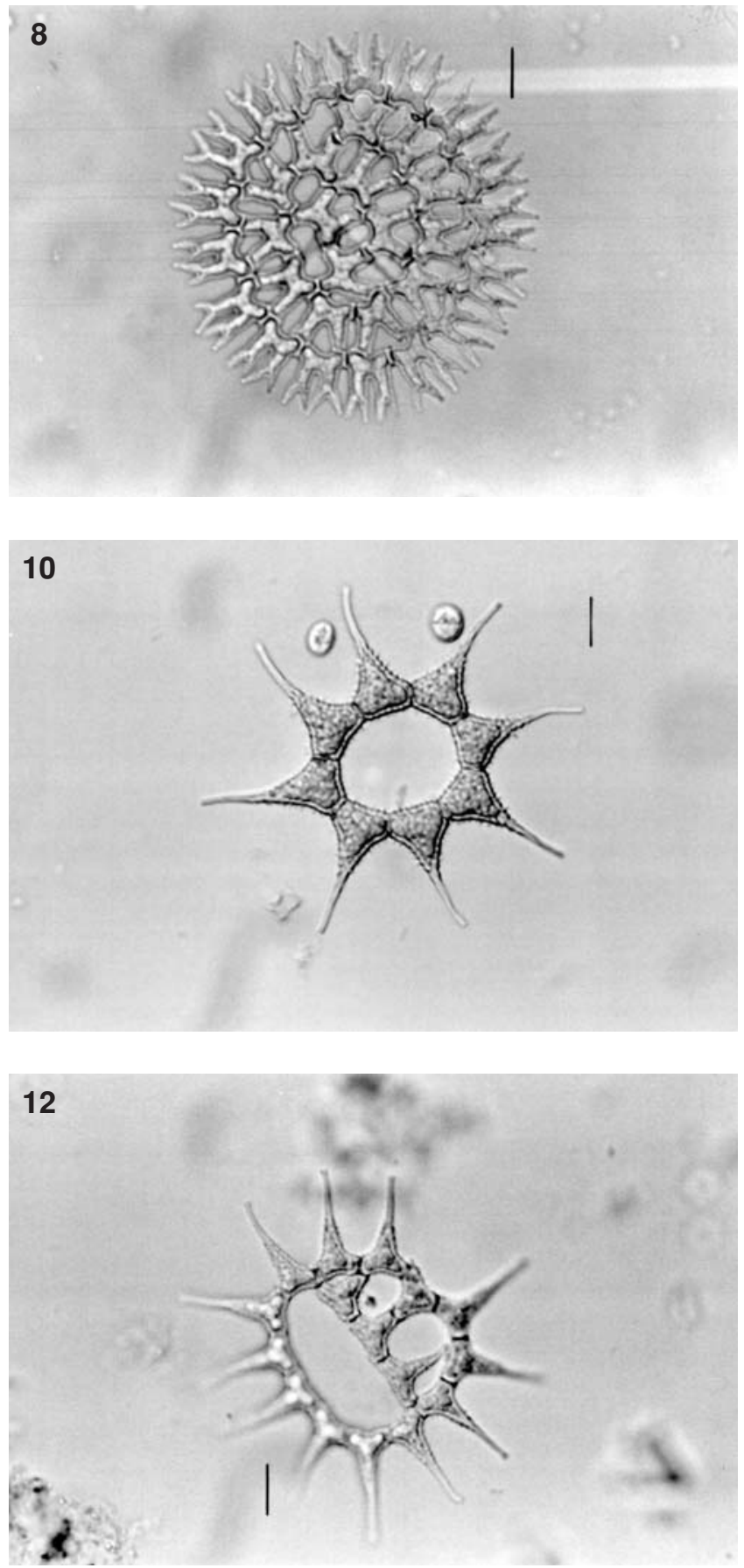

9

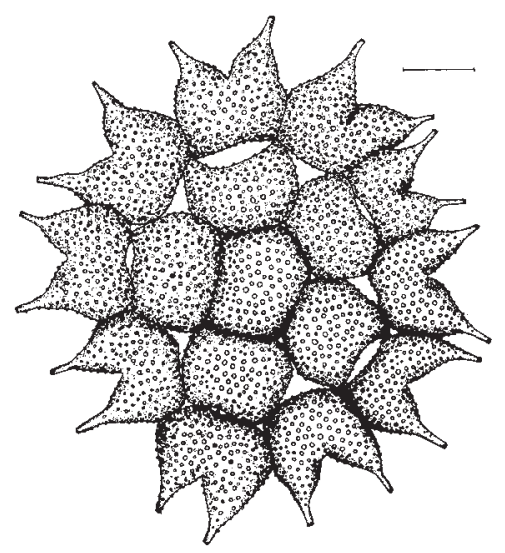

11

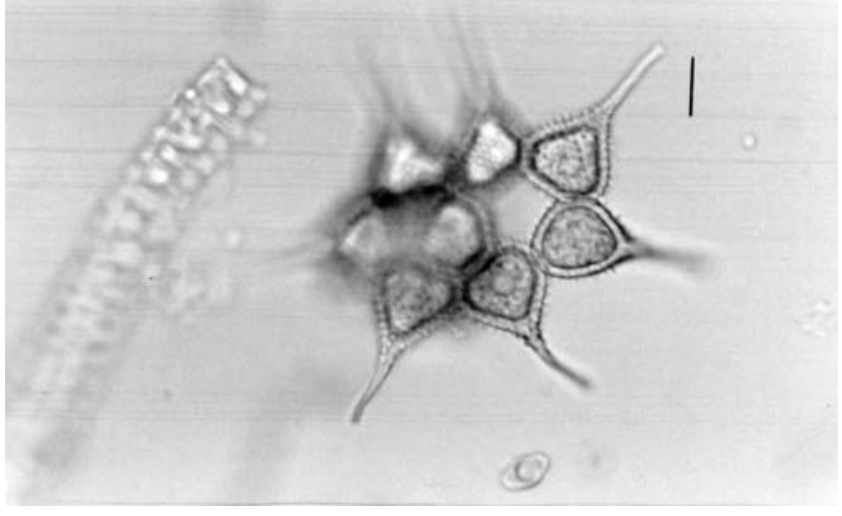

13

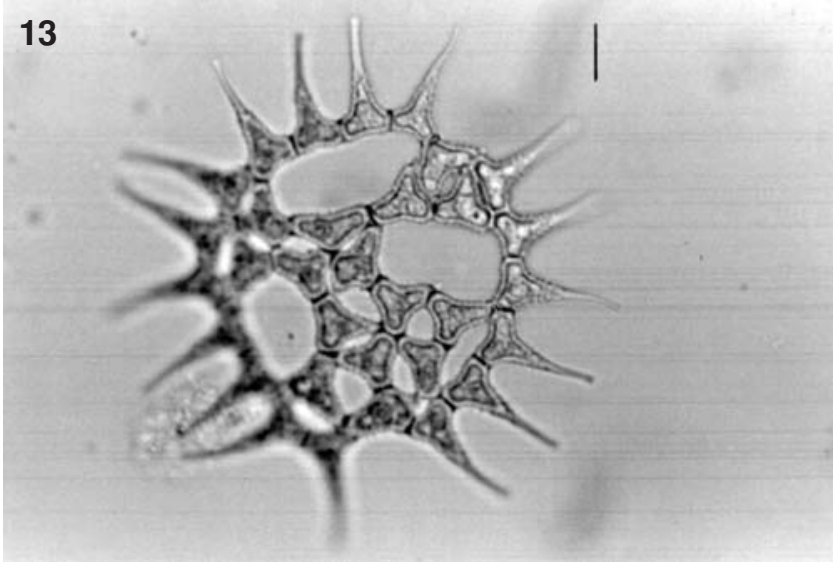

Fig. 8. Pediastrum biradiatum (Meyen) var. biradiatum. Scale bars: $10 \mu \mathrm{m}$. Focus level 800×.

Fig. 9. Pediastrum subgranulatum (Racib.) comb. nova. Scale bars: $10 \mu \mathrm{m}$.

Figs 10-11. Pediastrum simplex (Meyen) var. echinulatum Wittr. Scale bars: $10 \mu \mathrm{m}$. Focus level $800 \times$.

Figs 12-13. Pediastrum simplex (Meyen) var. clathratum (Schröt) Chod. Scale bars: $10 \mu \mathrm{m}$. Focus level 800×.

processies. Marginal and inner cells dimensions: 7.4-12.4 $\times$ 10.0-12.6 um. Cell walls smooth.

Typical planktic species; according to Komárek and Jankovská (2001) appears in temperate and subpolar regions in large, not very eutrophic lakes.

\section{Pediastrum tetras (Ehrenberg) (Fig. 7)}

Coenobia without holes between cells, 4-16 celled, rather small (diameter from 23.9 to $30.9 \mu \mathrm{m}$ ). Cells dimensions: marginal cells - 7.4-8.7 $\times$ 9.8-12.4 $\mu$ m, inner cells diameter 6.9-7.4 $\mu \mathrm{m}$. All cells have very narrow linear incision. Cell walls smooth.
One of the most common species in mesotrophic and eutrophic lakes (Komárek and Jankovská 2001).

\section{Pediastrum biradiatum (Meyen) var. biradiatum (Fig. 8)}

Coenobia circular in outline, with regular holes, sometimes as great as cell diameter, with 16-32 cells. The diameter of coenobium from 64.2 to $106.2 \mu \mathrm{m}$ (usually about 75 $\mu \mathrm{m})$. Cell walls with developed sculpture. Marginal cells 9.9-25.9 $\times 14.8-27.2 \mu \mathrm{m}$ with two lobes in the middle divided into to secondary lobes each. Inner cells diameter from 10.0-24.7 $\mu \mathrm{m}$. 

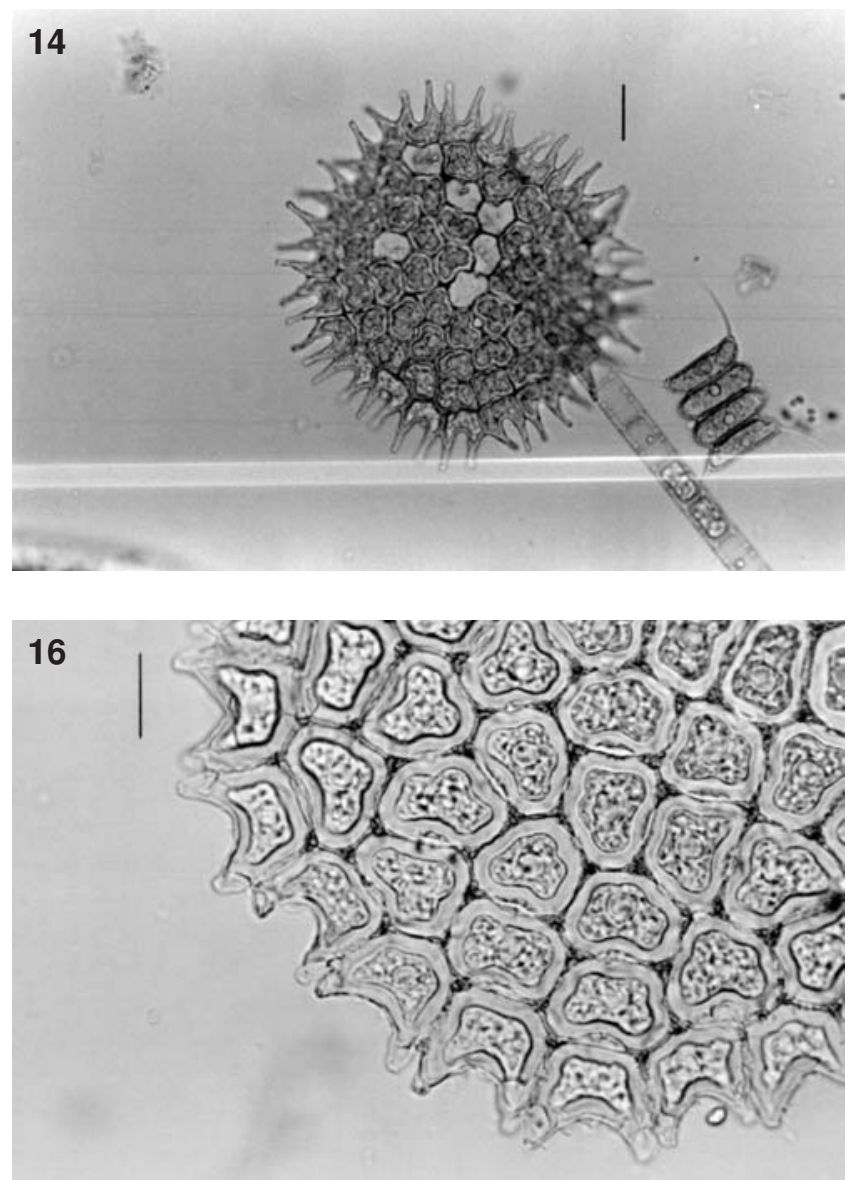

18

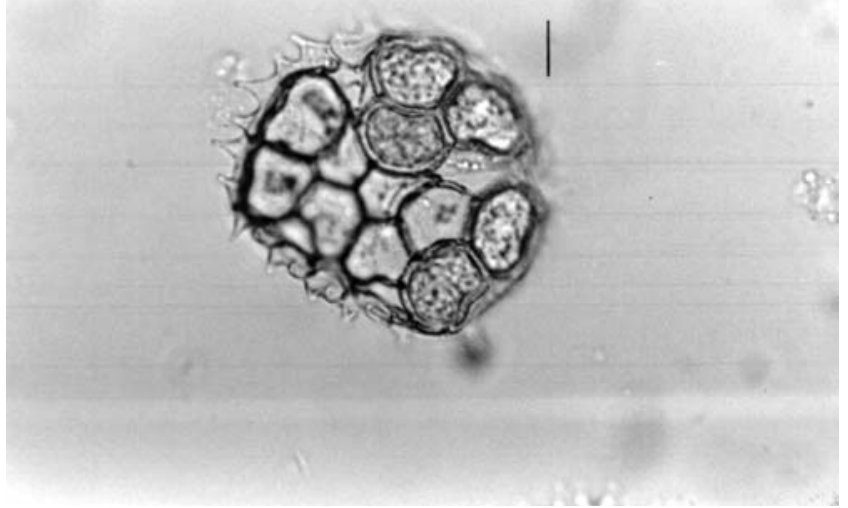

15

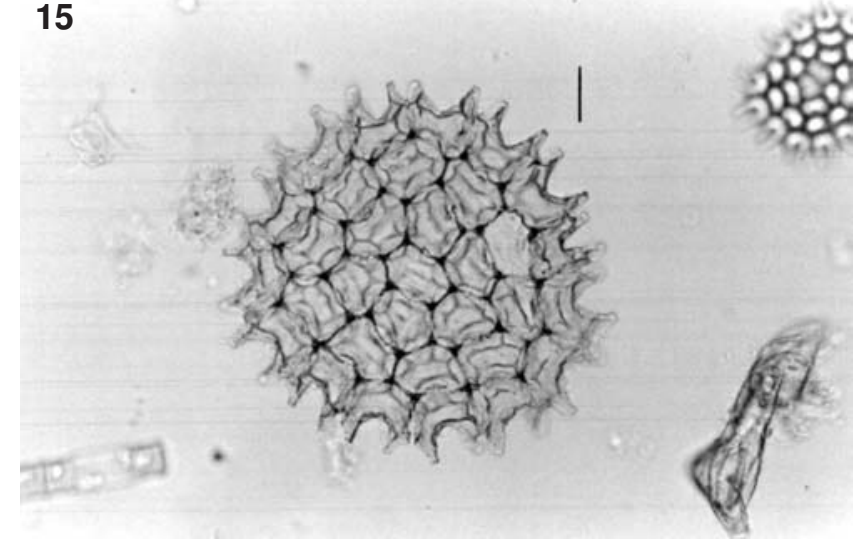

17

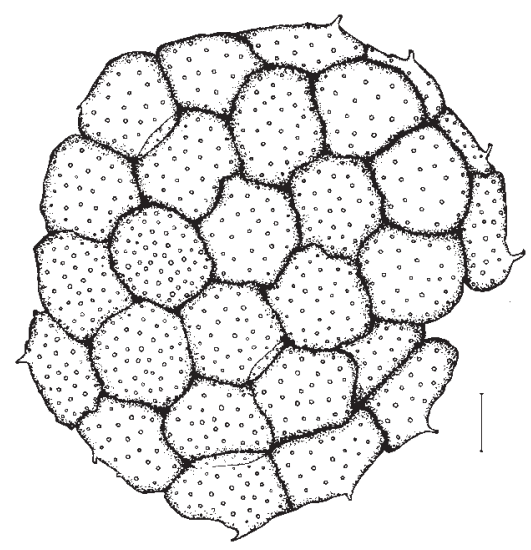

19

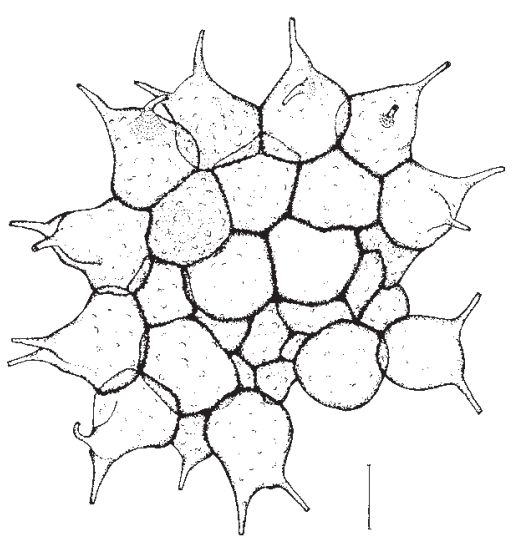

Fig. 14. Pediastrum alternans (Nygaard). Scale bars: $10 \mu \mathrm{m}$. Focus level $800 \times$.

Figs 15-16. Pediastrum angulosum (Ehrenberg) var. angulosum. Scale bars: $10 \mu \mathrm{m}$. Focus level 800× (Fig. 15). Focus level 1200× (Fig. 16). Fig. 17. Pediastrum integrum (Nägeli) var. integrum. Scale bars: $10 \mu \mathrm{m}$.

Fig. 18. Pediastrum integrum (Nägeli) (?). Scale bars: $10 \mu \mathrm{m}$. Focus level $800 \times$.

Fig. 19. Pediastrum kawraiskyi (Schmidle). Scale bars: $10 \mu \mathrm{m}$.

Species with cosmopolitan distribution, but not very common. It prefers non polluted waters and probably is termophylic (Komárek and Jankovská 2001).

\section{Pediastrum subgranulatum (Racib.) comb. nova (Fig. 9)}

Coenobia circular (69.7-84.6 $\mu \mathrm{m})$ with holes between cells, 16 celled. Inner cells rectangular 12.3-18.2 × 13.6$-19.9 \mu \mathrm{m}$, marginal cells with two long lobes (length with lobes - 18.9-23.5 $\mu \mathrm{m}$ ), width of marginal cells from 17.9 to $21.0 \mu \mathrm{m}$. Cell walls with prominent, dense, regular granulation.
In the key of Komárek and Fott (1983) this species is classified as $P$. duplex (Meyen) var. subgranulatum (Raciborski). $P$. subgranulatum has a cosmopolitan distribution, occurs in mesotrophic to slightly eutrophic waters but is not very common (Komárek and Jankovská 2001).

Pediastrum simplex (Meyen) var. echinulatum Wittr. (Figs 10, 11)

Coenobia circular if composed by $4-8$ cells, irregular in outline when 32 celled. Coenobia always with holes. Diameter of coenobia from 79.3-153.0 $\mu \mathrm{m}$. Marginal cells with 


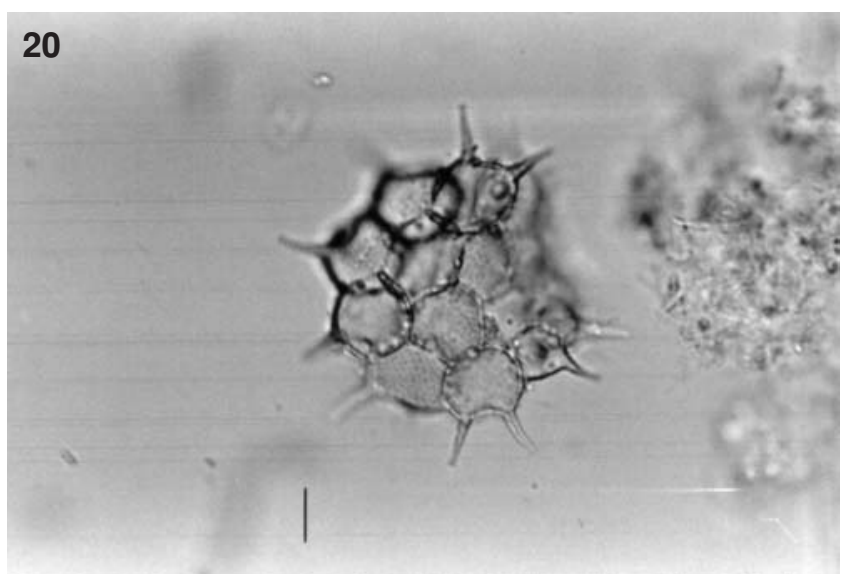

22

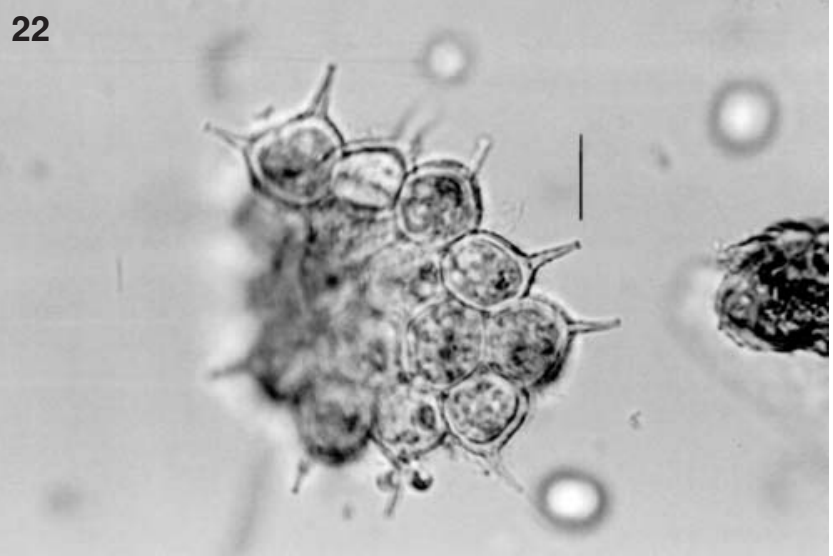

24

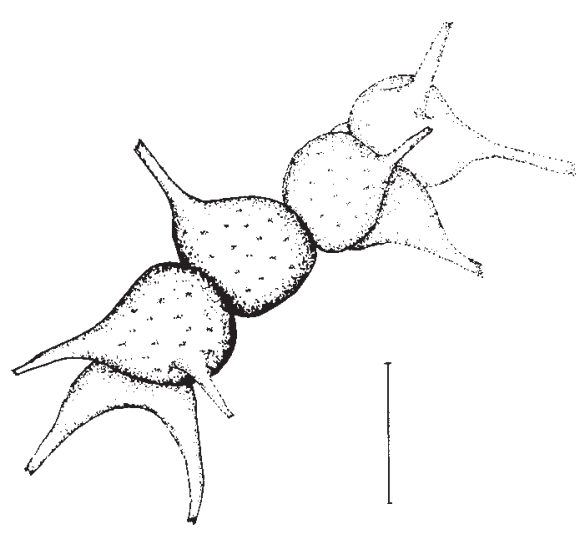

one narrowed lobe. Dimensions of marginal cells 12.2-22.2 $\times 29.6-37.1 \mu \mathrm{m}$ (with lobe). Diameter of inner cells from 12.4 to $17.3 \mu \mathrm{m}$. Cell walls with prominent, elongated granules.

$P$. simplex occurs in freshwater plankton of various eutrophic reservoirs with neutral to alkaline water, var. echinulatum was registered only in the north, temperate zone (Komárek and Jankovská 2001).

Pediastrum simplex (Meyen) var. clathratum (Schröt) Chod. (Figs 12, 13)

Coenobia always with irregular holes, the diameter of which is larger than the diameter of cells. Coenobium composed of 16-32 cells, diameter of coenobium from 74.1 to $153.1 \mu \mathrm{m}$. Cells walls delicate granular. Dimensions: marginal cells 10.0-22.2 × 24.7-46.9 $\mu \mathrm{m}$. Inner cells 7.4-22.4 $\times$ 7.4-25.0 $\mu \mathrm{m}$. Cell walls regularly granular.

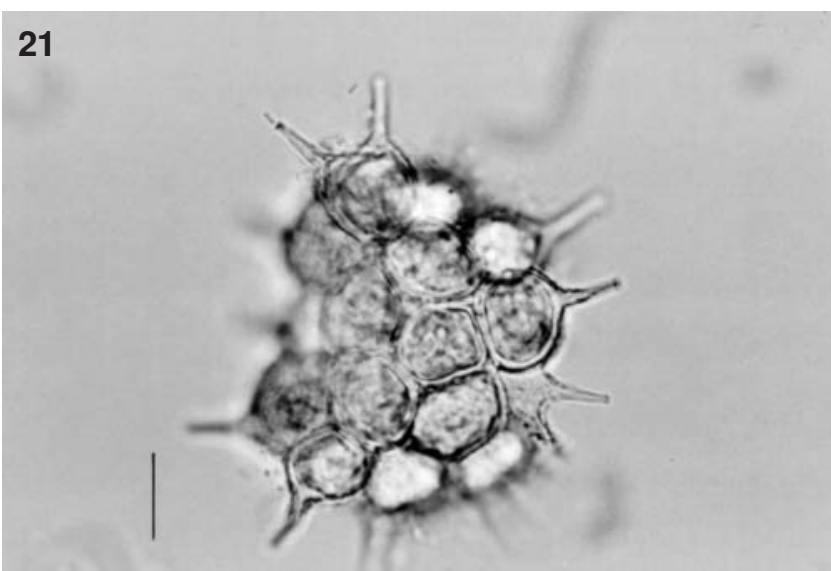

23

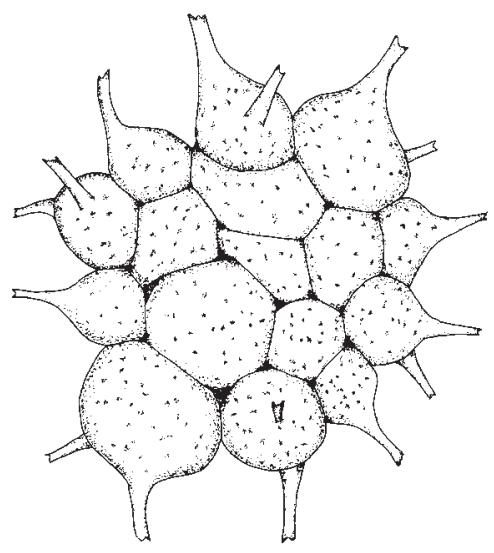

Figs 20-23. Pediastrum orientale (Skuja) Jankovská et Komárek. Scale bars: $10 \mu \mathrm{m}$. Focus level $800 \times$ (Fig. 20). Focus level 1200× (Fig. 21, 22). Fig. 24. Pediastrum orientale (Skuja) Jankovská et Komárek (in lateral view). Scale bars: $10 \mu \mathrm{m}$.

This species is almost worldwide, common particular in tropical lakes, in the temperate zone it appears during the warm season (Komárek and Jankovská 2001).

\section{To rare species found in Sumin Lake can be numbered:}

\section{Pediastrum alternans (Nygaard) (Fig. 14)}

Coenobia circular in outline (73.6-202.5 $\mu \mathrm{m})$ with very small irregular holes, 32-64 celled. The shape of each cell and lobes is slightly wavy. Marginal cells (7.0-24.7 × 10.0$34.6 \mu \mathrm{m})$ with U-like incisions. Inner cells: 9.0-19.7 $\times$ 15.5-23.5 $\mu \mathrm{m}$. Cell wall with delicate wavy sculpture.

This is a rare species described from lakes in Denmark, Finland and Sweden, according to Komárek and Jankovská (2001) probably of relict character. 
Pediastrum angulosum (Ehrenberg) var. angulosum (Figs $15,16)$

Coenobia circular or slightly oval from 86.5 to 180.3 $\mu \mathrm{m}$ in diameter (the most of individuals has about $140 \mu \mathrm{m}$ ) with 64-128 cells. Marginal cells with two lobes, incision between them U-like. Cell wall with well-marked net-like sculpture (Fig. 15). Dimensions of cells: marginal - 13.5$-19.8 \times 12.4-22.2 \mu \mathrm{m}$, inner cells - diameter from 10.0 to $22.2 \mu \mathrm{m}$.

Not very common species, according to palaeoalgological finds, it seems to indicate biotopes with a rich vegetation of submerged macrophytes (Komárek and Jankovská 2001).

\section{Pediastrum integrum (Nägeli) var. integrum (Fig. 17)}

Coenobia circular or irregular in outline, without holes, with 32 cells. Diameter of cenobia 88.9-94.0 $\mu \mathrm{m}$. Cells polygonal, arranged irregularly in cenobium. Marginal cells $(17.3-19.8 \times 10.0-12.4 \mu \mathrm{m})$ without incisions, with two short hyaline processes. Cell wall with distinct granulation. Diameter of inner cells: 14.8-17.3 $\mu \mathrm{m}$. Individuals, which had an untypical morphological structure, appeared very often in water samples form pelagial of Sumin Lake. Their coenobia resemble $P$. integrum, but on their rims there is always an additional layer of empty cells (Fig. 18).

$P$. integrum is distributed in cold, oligo and dystrophic water biotopes of northern and temperate regions (Komárek and Jankovská 2001).

\section{Pediastrum kawraiskyi (Schmidle) (Fig. 19)}

Coenobia circular in outline, sometimes irregular, without holes, 8-32-celled. Cells irregularly polygonal, concentrically arranged in cenobium. Its marginal cells are elongated and divaricated into two crosswise-oriented lobes. Marginal cells 7.4-12.1 um wide, 12.4-19.8 um long. Inner cells diameter between 10.0-14.8 $\mu \mathrm{m}$. Cell walls indistinctly granular.

A mass occurrence of $P$. kawraiskyi (especially with accompanying species $P$. integrum indicates cool, clean, oligotrophic water of large lakes (Jankovská and Komárek 2000), the present distribution is more restricted in comparison with fossil records and has a relict character (Komárek and Jankovská 2001).

\section{Pediastrum orientale (Skuja) Jankovská et Komárek (Figs 20-24)}

The special interesting Pediastrum-species which has been found in pelagial of Sumin Lake reasonables the little known alga - Pediastrum orientale found during the study of subfossil limnic sediments in the locality Švarcenberk (southern Bohemia, Czech Republic) by Jankovská and Komárek (1995). This species has been described originally as Pediastrum pearsonii var. orientale (Skuja 1937) from a clear mountain creek in Turkey. Later, Nygaard (1977), who has reported this variety from lakes in Greenland, changed its name into Pediastrum orientale. Pediastrum orientale was also found in subfossil sediments from the locality Lysmosen, Denmark (Nielsen and Sørensen 1992). The only locality of this species in Poland was reported by Wołowski et al. (2002) from "Żabie oko" peat bog in the Tatra Mountains. According to Iconotheca of Algae, collected at the Department of Phycology of the Institute of Botany, Polish Academy of Sciences, this species has not been reported from phytoplankton of Polish lakes.
The observed coenobia are slightly irregular in shape, but usually rounded (Figs 20-24). They are without holes between cells. The most of coenobia are lightly inflected, but some of them are flat. These coenobia are from 37 to $62 \mu \mathrm{m}$ in diameter and the cells are more or less regularly concentrically arranged. They are usually composed of 16 cells, rarely 32 polygonal or almost circular cells (marginal cells are usually more rounded than internal cells). Cell dimensions in coenobium composed of 16 cells are from 6-11.5 $\mu \mathrm{m}, 32$-cells coenobia had cell dimensions from 4.5$-5.2 \mu \mathrm{m}$. Cells are delicate granulated. Each marginal cell has two radially oriented, crossed processes, which are elongated, cylindrical and always longer then half the cell diameter, sometimes as long as the cell diameter. Ends of processes are truncated, but at the rim slightly dentate. Processes are from 5.04 to $7.56 \mu \mathrm{m}$ long and situated perpendicularly to the plane of the coenobium. Protoplast fills the cells, but it does not reach the processes. Pediastrum-species described above was observed in samples of pelagic water from spring till autumn.

We suppose that the observed Pediastrum-species from Sumin Lake could be taxonomically classified as the same species - Pediastrum orientale found by Skuja (1937), Nygaard (1977), Nielsen and Sørensen (1992), Jankovská and Komárek (2001). However, several small differences have been found in our taxon. The main difference was that processes are much longer and sometimes reached up to cell diameter, whereas processes of $P$. pearsonii var. orientale described by Skuja (1937) and Nygaard (1977) are usually shorter than half of the cell diameter. Singular-cell dimension was also never greater than $11.5 \mu \mathrm{m}$, while Skuja (1937) and Jankovská and Komárek (1995) reported Pediastrum has cell dimensions $10-16 \mu \mathrm{m}$ in diameter. An ecological dissimilarity is that Pediastrum orientale populations found as yet settled cold, clear water biotopes not highly eutrophic (Jankovská and Komárek 2001). In spite of above the mentioned differences, most of the diacritical features are the same, like in $P$. orientale described in the key of Jankovská and Komárek (2001).

Some observed taxa of the genus Pediastrum as $P$. boryanum, $P$. duplex, $P$. biradiatum, $P$. tetras are common, appeared in water bodies and were noted in Poland - in rivers (Ligowski 1988), ponds (Sitkowska 1992), and lakes (Wojciechowska and Pęczuła 1999). All noted taxa of Pediastrum are rather alkalifilic and occur in mesotrophic to eutrophic water bodies, except of $P$. orientale and $P$. integrum, which prefer oligotrophic biotopes. According to Komárek Jankovská and (2001), very rare species as $P$. integrum and $P$. kawraiskyi have the character of relicts and occur in biotopes that are endangered in the present world.

\section{ACKNOWLEDGMENTS}

The authors would like to thank Dr M. Luścińska and Assist. Prof. K. Wołowski for valuable comments helpful in preparation of this work.

\section{LITERATURE CITED}

BAŁAGA K. 1998. Późnoglacjalny i wczesnoholoceński etap rozwoju jeziora Karaśnego i torfowiska wysokiego Durne Ba- 
gno na Polesiu Lubelskim. Materiały konferencji i obrad sekcji 51 Zjazdu PTB - Gdańsk, pp. 19. (in Polish)

HARASIMIUK M., WOJTANOWICZ J. 1998. Budowa geologiczna i rzeźba terenu Pojezierza Łęczyńsko-Włodawskiego. In: Jeziora Łęczyńsko-Włodawskie. Monografia przyrodnicza. Harasimiuk M., Michalczyk Z., Turczyński M. (ed.). Biblioteka Monitoringu Środowiska, Lublin, pp. 41-50. (in Polish)

JANKOVSKÁ V., KOMÁREK J. 1995. Pediastrum orientale from subfossil layers. Folia Geobot. Phytotax. 30: 319-329.

JANKOVSKÁ V., KOMÁREK J. 2000. Indicative value of $P e-$ diastrum and other coccal green algae in palaeoecology. Folia Geobot. 35: 59-82.

KOMÁREK J., FOTT B. 1983. Chlorophyceae (Grünalgen). Ordunung: Chlorococcales. In: Das Phytoplankton des Süsswassers. Systematik und Biologie. Huber-Pestalozzi G. (ed.), Schweizerbart'sche Verlagsbuchhandlung, Stuttgart, Teil 7, Hälfte 1, pp. 283-308.

KOMÁREK J., JANKOVSKÁ V. 2001. Review of the Green Algal Genus Pediastrum; Implication for Pollen-analytical Research. Bibliotheca Phycologica. Cramer J. Berlin-Stuttgart, pp. 108.

LIGOWSKI R. 1988. The spatial and seasonal density of sessile algae in the River Bobrówka and some ponds situated along its course (Central Poland). Acta Hydrobiol. 30 (1/2): 209-224.

MALICKI J. 1972. Rodzaj Pediastrum Meyen w jeziorach Pojezierza Łęczyńsko-Włodawskiego. Ann. Univ. Mariae CurieSkłodowska, Lublin, Sectio C, 23: 271-280. (in Polish with English summary)

NICHOLLS K.H. 1997. Planctonic green algae in western Lake Erie: the importance of temporal scale in the interpretation of change. Fresh. Biol. 38: 419-425.

NIELSEN H. 2000. Morphometric analysis of cell wall sculpture in seven infraspecific taxa of Pediastrum boryanum (Sphaeropleales, Chlorophyta) and its taxonomic implications. Phycologia 39 (1): 36-49.
NIELSEN H., SØRENSEN I. 1992. Taxonomy and striatigraphy of the Late-Glacial Pediastrum taxa from Lysmosen, Denmark - a preliminary study. Rev. Paleobot. Palynol. 74: 55-75.

NYGAARD G. 1977. New or interesting plankton algae. Kongel. Danske Vidensk. Selsk. Biol. Skr. 21 (1): 1-707.

RADWAN S., KORNIJÓW R. 1998. Hydrobiologiczne cechy jezior - stan aktualny i kierunki zmian. In: Jeziora łęczyńskowłodawskie. Monografia przyrodnicza. Harasimiuk M., Michalczyk Z., Turczyński M. (ed.). Biblioteka Monitoringu Środowiska, Lublin, pp. 129-144. (in Polish)

REYNOLDS C.S. 1980. Phytoplankton assemblages and their periodicity in stratifying lake systems. Holarctic Ecol. 3: 141-159.

SITKOWSKA M. 1992. Taksony rodzaju Pediastrum Meyen występujące w stawach Łodzi i okolicy. Acta Univ. Lodz., Folia Bot. 9: 47-104. (in Polish with English summary)

SKUJA H. 1937. Süsswasseralgen aus Griechenland und Klein Asien. Nowa Hedwigia 77: 15-70.

SULEK J. 1969. Taxonomische Übersicht der Gattung Pediastrum Meyen. In: Studies in phycology. Fott B. (ed.). Praha, pp. 197-261.

WOJCIECHOWSKA W., PĘCZUŁA W. 1999. Struktura jakościowa i ilościowa fitoplanktonu. In: Ekosystemy wodne i lądowe Sobiborskiego Parku Krajobrazowego i ich ochrona. Wojciechowska W. (ed.). Redakcja Wydawnictw KUL, Lublin, pp. 77-81. (in Polish)

WOJCIECHOWSKI I. 1971. Die Plankton-Flora der Seen in der Umgebung von Sosnowica (Ostpolen). Ann. Univ. Mariae Curie-Skłodowska, Sectio C, 20: 233-263.

WOJCIECHOWSKI I. 1983. Glony jezior Łęczyńsko-Włodawskich. In: Środowisko Przyrodnicze Lubelskiego Zagłębia Węglowego. TWWP, Lublin, pp. 97-110. (in Polish)

WOŁOWSKI K., OBIDOWICZ A., WAWRZYCKA I. 2002. Pediastrum species (Chlorophyceae) in Quaternary sediments of "Żabie Oko" peat bog in the Tatra Mts. Acta Palaeobot. 42 (1): 51-61. 